\title{
Galanin receptors and ligands
}

\author{
Kristin E. B. Webling ${ }^{1}{ }^{*}$, Johan Runesson ${ }^{1}$, Tamas Bartfai ${ }^{2}$ and Ülo Langel ${ }^{1,3}$ \\ 1 Department of Neurochemistry, Arrhenius Laboratories for Natural Science, Stockholm University, Stockholm, Sweden \\ ${ }^{2}$ Molecular and Integrative Neurosciences Department, The Scripps Research Institute, La Jolla, CA, USA \\ ${ }^{3}$ Institute of Technology, University of Tartu, Tartu, Estonia
}

Edited by:

Jae Young Seong, Korea University,

Korea

Reviewed by:

Jong-lk Hwang, Korea University,

Korea

Sebastien G. Bouret, University of

Southern California, USA

*Correspondence:

Kristin E. B. Webling, Department of

Neurochemistry, Arrhenius

Laboratories for Natural Science,

Stockholm University, Svante

Arrheniusv. 21A, 10691 Stockholm

Sweden.

e-mail: kristin.webling@neurochem.

su.se
The neuropeptide galanin was first discovered 30 years ago. Today, the galanin family consists of galanin, galanin-like peptide (GALP), galanin-message associated peptide (GMAP), and alarin and this family has been shown to be involved in a wide variety of biological and pathological functions. The effect is mediated through three GPCR subtypes, GalR1-3. The limited number of specific ligands to the galanin receptor subtypes has hindered the understanding of the individual effects of each receptor subtype. This review aims to summarize the current data of the importance of the galanin receptor subtypes and receptor subtype specific agonists and antagonists and their involvement in different biological and pathological functions.

Keywords: galanin, galanin-like peptide, GMAP, alarin, epilepsy

\section{THE GALANIN FAMILY}

Since the discovery of galanin 30 years ago, several bioactive peptides have been reported to be part of the galanin family. The discovery of galanin was followed by the characterization of a second peptide originating from the same prepropeptide as galanin, the galanin message associated peptide (GMAP). Furthermore, a third peptide, GALP, was identified with capacity to bind to the galanin receptor subtypes, GalR1-3, followed by the characterization of a splice variant of GALP named alarin.

\section{GALANIN}

Galanin was discovered among several other bioactive peptides with C-terminal $\alpha$-amide motif, using a new method by Professor Viktor Mutt and colleagues at Karolinska Institute, Stockholm (Tatemoto et al., 1983; Hökfelt, 2005; Lang et al., 2007). The 29 amino acid long peptide (30 amino acids in humans) was named galanin after its $\mathrm{N}$-terminal glycine and its $\mathrm{C}$-terminal alanine. The $\mathrm{N}$-terminal end of galanin is crucial for its biological activity and the first 15 amino acids are conserved in all species (the tuna fish being the exception; Kakuyama et al., 1997). Interestingly, the C-terminal region (residues 17-29) varies among species and it lacks receptor affinity (Table 2), which is also true for $\mathrm{N}$-terminal fragments shorter than galanin (1-11) (Land et al., 1991b). The C-terminus is believed to primarily serve as a protector against proteolytic attacks (Land et al., 1991a; Bedecs et al., 1995). In a membrane-mimicking environment, galanin adopts a horseshoelike shape, where the $\mathrm{N}$-terminus is organized in an $\alpha$-helical conformation, followed by a $\beta$-bend around the proline in position 13 and a more uncertain configuration of the C-terminal region (Wennerberg et al., 1990; Morris et al., 1995, Öhman et al., 1998).

Galanin has been ascribed a large range of different functions. To accomplish these, the galanin gene has a highly plastic expression pattern, which has been portrayed numerous times in the literature. Galanin was early shown to be induced by estrogens (Vrontakis et al., 1987, 1989; Kaplan et al., 1988), and later, three copies of estrogen responsive element, ERE, were identified in the promoter region of the human galanin gene (Kofler et al., 1995). Thereafter, the galanin expression has also been shown to be up-regulated by the leukemia inhibitory factor (LIF; Corness et al., 1996; Sun and Zigmond, 1996), and down-regulated by the nerve growth factor (NGF; Verge et al., 1995).

Galanin is widely expressed in the central and peripheral nervous system as well as in the endocrine system and co-exists with a number of classical neurotransmitters, including acetyl choline, serotonin, glutamate, GABA, noradrenalin, and dopamine (Melander et al., 1986; Hökfelt et al., 1987; Xu et al., 1998; Liu et al., 2003). Galanin also co-exists with other neuropeptides like enkephalin, NPY, substance P, vasopressin, calcitonin generegulated peptide, and gonadotropin-releasing hormone (Rökaeus and Carlquist, 1988; Merchenthaler et al., 1990; Zhang et al., 1993a,b, 1995).

An extensive up-regulation of galanin was seen during development of sensory and motor systems (Gabriel et al., 1989; Xu et al., 1996) and after nerve injury, both in PNS and CNS (Hökfelt et al., 1987) and also, an extensive up-regulation in the basal forebrain of patients with Alzheimer's disease (AD; Chan-Palay, 1988a,b). Epileptic seizures have been shown to rapidly deplete galanin (Mazarati et al., 1998).

Galanin has also been shown to be expressed in keratinocytes, eccrine sweat glands and around blood vessels (Kofler et al., 2004). Furthermore, galanin has been proposed to be expressed in macrophages of the dermis (reviewed in Bauer et al., 2010). 


\section{GALANIN MESSAGE ASSOCIATED PEPTIDE}

There are very few studies regarding the localization, function, and pharmacological potential of GMAP. It was early shown that the sequence of GMAP displays a much greater divergence between species than galanin (Lundkvist et al., 1995). Immunohistochemistry has shown that GMAP distribution generally parallels that of galanin (Hökfelt et al., 1992) although heterologous distribution was observed in certain areas. Xu et al. (1995a,b) showed that GMAP has a pharmacological action in spinal nociceptive transmission in rat spinal cord (Andell-Jonsson et al., 1997; Hao et al., 1999). GMAP has also been assigned anti-microbial activities and hypothesized to be part of the innate immune system, since it suppresses Candida albicans growth and the budded-to-hyphalform transition of C. albicans (Rauch et al., 2007) (Table 1). Recently, in an extended study, it was shown that GMAP could significantly reduce growth in six out of seven Candida strains (Holub et al., 2011).

\section{GALANIN-LIKE PEPTIDE}

Ohtaki et al. (1999) characterized a third peptide, isolated from porcine hypothalamus, that was recognized to induce GTPbinding to a membrane preparation of GalR2-transfected cells. They named this new peptide galanin-like peptide, or GALP. Porcine GALP was shown to act as an agonist in a GTP $\gamma \mathrm{S}$ binding

Table 1 | A short summary of the involvement of the galanin family in different physiological and pathological functions.

Agonist Antagonist

\section{GALANIN RECEPTOR 1}

Reduces acetylcholine release in cardiac neurons (Potter and Smith-White, Anxiolytic and antidepressant (Kuteeva et al., 2008)

2005)

Antinocicepive effects for neuropathic pain (Liu et al., 2001)

Improving memory and learning Mrenn et al., 2004; Bailey et al., 2007)

Treatment for diseases of altered extrinsic afferent signaling around that

gastrointestinal tract (Page et al., 2007)

Anticonvulsant, reduces initiation of seizures (Mazarati et al., 2004b; Bulaj

et al., 2008)

\section{GALANIN RECEPTOR 2}

Neuroprotective effects against Alzheimer's disease (Pirondi et al., 2010)

Anxiolytic and antidepressant (Kuteeva et al., 2008)

Anticonvulsant by reduction of severity of seizures (Mazarati et al., 2004a;

Robertson et al., 2010)

\section{GALANIN RECEPTOR 3}

Inhibit oxytocin secretion (Radács et al., 2010)

Anxiolytic and antidepressant (Swanson et al., 2005; Kuteeva et al., 2008;

Ash et al., 2011)

Reduced alcohol consumption (Ash et al., 2011)

Reduces severity of acute pancreatitis (Barreto et al., 2011)

\section{EXOGENOUS GALANIN}

Increases heart rate, induces tachycardia and a weak vasodepressor response (Narváez et al., 2000)

Impaired performance in memory tests Wrenn et al., 2004; Bailey et al., 2007)

Increases alcohol intake (Schneider et al., 2007)

Inhibit the secretion of vasopressin and oxycotin (Ciosek and Cisowska, 2003; Izdebska and Ciosek, 2010; Radács et al., 2010)

Anticonvulsant effects (Mazarati et al., 1992, 1998, 2000, 2004b; Chepurnov et al., 1998; Lu et al., 2010; Robertson et al., 2010,)

Anti-nociceptive (Xu et al., 2012)

Neuroprotective effects against Alzheimer's disease (Pirondi et al., 2010) Anxiolytic- and antidepressant (Kuteeva et al., 2008)

\section{EXOGENOUS GALP}

In rats: an acute increase (30-60 min) of food intake, followed by reduction in food intake (Lawrence, 2009), increased sexual behavior in male rats (Fraley et al., 2004)

In mice: decreased food intake (Lawrence, 2009), an acute decrease in body temperature followed by an increase in body temperature (Man and Lawrence

2008a)

Inhibition of male sexual behavior in mice (Kauffman et al., 2005)

\section{EXOGENOUS ALARIN}

In male mice: Increase of acute food intake, acute increase of body weight, increased LH levels, decrease of neurogenic inflammation, no change in body temperature (Fraley et al., 2012)

Anti-edema and vasoconstrictive effects (Santic et al., 2007)

Increases LH levels in mice and rats (Boughton et al., 2010; van Der Kolk et al., 2010; Fraley et al., 2012)

\section{EXOGENOUS GMAP}

Anti-microbial activities (Rauch et al., 2007; Holub et al., 2011)

Facilitation of the flexor reflex, decrease of spinal cord blood flow (Xu et al., 1995a) 
Table 2 | Affinities of galanin, GALP, GMAP, and alarin, as well as fragments of galanin and GALP, for the three galanin receptor subtypes, determined as $\mathbf{K}_{\mathbf{i}}$.

\begin{tabular}{|c|c|c|c|c|}
\hline Ligand & \multicolumn{3}{|c|}{$K_{\mathrm{i}}(\mathrm{nM})$} & Reference \\
\hline \multirow{2}{*}{ Rat galanin(1-29) } & $0.3(h)$ & $1.6(h)$ & 12 (h) & Borowsky et al. (1998) \\
\hline & $0.9(h)$ & $1.2(h)$ & $7.4(h)$ & Lu et al. (2005b) \\
\hline Human galanin(1-30) & $0.4(h)$ & $2.3(h)$ & $69(h)$ & Borowsky et al. (1998) \\
\hline Galanin(1-16) & 4.8 & 5.7 & 50 & Wang et al. (1997b) \\
\hline Galanin(2-29) & 85 & 1.9 & 12 & Wang et al. (1997b) \\
\hline Galanin(3-29) & $>1000$ & $>1000$ & $>1000$ & Wang et al. (1997b) \\
\hline \multirow[t]{2}{*}{ Galanin(2-11) } & $>5000$ (h) & 88 & 271 & Lu et al. (2005a) \\
\hline & $879^{a}(h)$ & $1.8^{\mathrm{a}}$ & - & Liu et al. (2001) \\
\hline Porcine GALP & 4.3 & 0.24 & - & Ohtaki et al. (1999) \\
\hline Rat GALP & $45^{a}$ & $18.7^{\mathrm{a}}$ & $1530^{\mathrm{a}}(\mathrm{h})$ & Boughton et al. (2010) \\
\hline Alarin & $>1000$ & $>1000$ & $>1000000$ & Boughton et al. (2010) \\
\hline \multirow[t]{2}{*}{$\operatorname{GMAP}(1-41)$} & - & $>840$ & - & Wang et al. (1997a) \\
\hline & - & - & $>1000$ & Wang et al. (1997b) \\
\hline GMAP(44-59) & - & $>1000$ & $>1000$ & Wang et al. (1997b) \\
\hline
\end{tabular}

Displacement is performed on the rat galanin receptor unless indicated otherwise. (h) human; ${ }^{a}$ presented as $I C_{50}$ values; - not determined.

assay and to have a preferential binding (20 times) toward GalR2 (Ohtaki et al., 1999). A later study using human GALP showed that GALP interacts with GalR3 with three times preferential selectivity as compared to GalR2 (Lang et al., 2005) (Table 2).

The amino acid sequence of GALP-(9-21) is identical to that of galanin (1-13).

Galanin-like peptide distribution in the CNS appears to be rather restricted, disparate to the much broader expression pattern seen for galanin. Cells identified to produce GALP mRNA and protein have only been found in the hypothalamic arcuate nucleus (ARC), the median eminence and infundibular stalk, and the posterior pituitary when studied in the rat, mouse, and macaque (Juréus et al., 2000, 2001; Kerr et al., 2000; Larm and Gundlach, 2000; Takatsu et al., 2001; Cunningham et al., 2002; Fujiwara et al., 2002). GALP-immunoreactive (IR) fibers were shown to project to several regions of the forebrain (Takatsu et al., 2001).

Galanin-like peptide has also been shown to be expressed by specialized glia-like cells known as pituicytes in the neuronal lobe of dehydrated and salt loaded rats, where the expression is strongly regulated by osmotic stimuli (Shen et al., 2001; Fujiwara et al., 2002; Saito et al., 2003; Shen and Gundlach, 2004). Furthermore, studies show that the GALP gene expression, especially in the pituicytes, is induced by both acute and chronic inflammatory stimuli (Saito et al., 2003, 2005). Central administration of GALP increases IL- $1 \alpha$ and IL- $1 \beta$ and it has been suggested that IL- 1 mediates both the anorectic and febrile actions of GALP (Man and Lawrence, 2008b).

Intracerebroventricular (i.c.v.) injection of GALP profoundly stimulates male sex behaviors in rat (Fraley et al., 2004), seemingly independent of the testosterone milieu (Stoyanovitch et al., 2005) (Table 1). Interestingly, the opposite is seen in mice were GALP instead inhibits male sex behavior (Kauffman et al., 2005). Recently, Taylor et al. (2009) presented evidence supporting the hypothesis that this effect of GALP depends upon hypothalamic dopamine input to the medial preoptic area (mPOA).

Several studies have proposed that GALP does not solely interact with the three known galanin receptor subtypes (Man and Lawrence, 2008a). Krasnow et al. (2004) reported that GALP injection affect food intake and body weight in a similar manner in both GalR1-KO and GalR2-KO mice compared to wild type littermates. Furthermore, to somewhat exclude the possibility that this effect was mediated through GalR3, the authors showed that the GALP fragment, GALP (1-21), failed to mimic the effect of full length GALP (Krasnow et al., 2004).

\section{ALARIN}

The newest member of the galanin peptide family, alarin, a 25 amino acid long peptide named after its $\mathrm{N}$-terminal alanine and its C-terminal serine originating as a splice variant of the GALP mRNA (Santic et al., 2006). The alarin peptide has been isolated from murine brain, thymus, skin (Santic et al., 2007), human neuroblastic tumors, and human skin (Santic et al., 2006, 2007) and has no detectable affinity toward either of the three galanin receptor subtypes (Boughton et al., 2010) (Table 2). Recently, two publications characterized in more detail the alarin-LI in the murine brain (van Der Kolk et al., 2010; Eberhard et al., 2012). Alarin-LI has a much broader expression pattern than GALP and was found in such diverse areas as the accessory olfactory bulb, 
different nucleus in the hypothalamus, within the locus coeruleus (LC) and locus subcoeruleus of the midbrain.

When first discovered, alarin was ascribed vasoconstrictive and anti-edema activities (Santic et al., 2007) (Table 1). Contradictory to the effect of GALP, alarin has neither an effect on body temperature nor an effect on male sex behaviors in rodents (van Der Kolk et al., 2010; Fraley et al., 2012). Recently, it was shown that alarin stimulates acute food intake and some studies have reported a significant increase in body weight after $24 \mathrm{~h}$, although other studies were unable to confirm this (Boughton et al., 2010; van Der Kolk et al., 2010; Fraley et al., 2012). Central injection of alarin elicit a gonadotrophin-releasing hormone (GnRH)-mediated increase in leutizing hormone (LH)-levels in both rats and mice (Boughton et al., 2010; van Der Kolk et al., 2010; Fraley et al., 2012).

\section{GALANIN RECEPTOR SUBTYPES}

All three galanin receptor subtypes are members of the GPCR superfamily but the subtypes have substantial differences in sites of expression as well as their functional coupling and subsequent signaling activities. These differences between the receptor subtypes contributes to the diversity of possible physiological effects and the plausible pharmacological relevance of targeting the galanin family (Table 1).

\section{GALANIN RECEPTOR TYPE 1}

The first known galanin receptor, galanin receptor type 1 (GalR1), was isolated from the Bowes human melanoma cell line (HabertOrtoli et al., 1994) and subsequently rat (Burgevin et al., 1995; Parker et al., 1995) and mouse (Jacoby et al., 1997; Wang et al., 1997c) receptor was cloned.

The human GalR1 gene contains three exons and the hGalR1 gene translates into a 349 amino acid long protein (Jacoby et al., 1997). The homology between species is rather high, as $93 \%$ of the residues in rat GalR1 are identical to those of human GalR1 (Jacoby et al., 1997). The expression of GalR1, but neither GalR2 nor GalR3, is regulated by cyclic adenosine monophosphate (cAMP) through the transcription factor CREB (cAMP regulatory element binding protein; Zachariou et al., 2001; Hawes et al., 2005). The GalR1 expression does not fluctuate during development (Branchek et al., 2000; Burazin et al., 2000).

GalR1 mRNA was initially identified by northern blot to be found in the fetal brain and small intestinal tissues (Habert-Ortoli et al., 1994). It has, thereafter, been identified by reverse transcript polymerase chain reaction (RT-PCR) in the gastrointestinal tract (Lorimer and Benya, 1996). However, a later study identified the GalR1 expression to be exclusively in the central and peripheral nervous system (Waters and Krause, 2000), where it was detected in hippocampus, hypothalamus, amygdala, thalamus, cortex, brainstem (medulla oblongata), spinal cord, and dorsal root ganglia (DRG; Gustafson et al., 1996; Waters and Krause, 2000), even if broader central and peripheral tissue distribution has also been reported (Sullivan et al., 1997).

Activation of GalR1 results in a pertussis toxin (PTX) sensitive inhibition of adenylate cyclase $(\mathrm{AC})$ through interaction with $\mathrm{G} \alpha_{\mathrm{i}} / \alpha_{\mathrm{o}}$ types of G-proteins (Habert-Ortoli et al., 1994; Parker et al., 1995; Wang et al., 1997c) which leads to opening of GIRK channels. Activation of GalR1 can also stimulate a mitogen associated protein kinase (MAPK) activity, through a $\mathrm{PKC}$-independent mechanism, consistent with that the mediator is the $\beta \gamma$-subunit of $\mathrm{G} \alpha_{\mathrm{i}}$ (Wang et al., 1998).

\section{GALANIN RECEPTOR TYPE 2}

The second galanin receptor type (GalR2) was identified in rat hypothalamus, spinal cord, and DRG (Fathi et al., 1997; Howard et al., 1997; Smith et al., 1997; Ahmad and Dray, 2004) and subsequently in mouse spleen (Pang et al., 1998) as well as from various human tissues (Bloomquist et al., 1998; Borowsky et al., 1998). The human GalR2 has rather high sequence identity to rat GalR2 (92\%), although there is one notable difference; the 15 amino acid extension of the C-terminal end in human GalR2 (Kolakowskim et al., 1998; Waters and Krause, 2000).

GalR2 is able to activate the stimulatory pathway of $\mathrm{G} \alpha_{\mathrm{q} / 11}$ class of G-proteins, i.e., PTX-insensitive. This triggers PLC activity and intracellular phosphoinositol turnover, mediating the release of $\mathrm{Ca}^{2+}$ into the cytoplasm from intracellular stores and opening $\mathrm{Ca}^{2+}$-dependent channels (Smith et al., 1997; Kolakowskim et al., 1998; Wang et al., 1998). GalR2 is also able to activate MAPK through a PKC and $\mathrm{G} \alpha_{o}$ class of G-proteins dependent mechanism (Wang et al., 1998). This may in turn lead to the downstream PI3K-dependent phosphorylation of Protein Kinase B (PKB) leading to suppression of caspase-3 and caspase-9 activity (Ding et al., 2006; Elliott-Hunt et al., 2007). GalR2 activation may also inhibit forskolin stimulated cAMP production in a PTX-sensitive manner, suggesting the activation of $\mathrm{G} \alpha_{\mathrm{i}} / \alpha_{\mathrm{o}}$ types of G-proteins (Fathi et al., 1997; Wang et al., 1997a). Consequently, both GalR1 and GalR2 activation can inhibit CREB (Badie-Mahdavi et al., 2005).

GalR2 is expressed in a wider pattern, compared to GalR1, as it is found in several peripheral tissues including the pituitary gland, gastrointestinal tract, skeletal muscle, heart, kidney, uterus, ovary, and testis as well as in regions in the CNS (Smith et al., 1997; Bloomquist et al., 1998; Waters and Krause, 2000). In the brain, the highest levels of GalR2 are detected in hypothalamus, dentate gyrus, amygdala, piriform cortex, and mammillary nuclei (Mitchell et al., 1999; O’Donnell et al., 1999; Waters and Krause, 2000).

Interestingly, GalR2 expression levels vary during the development of the rat brain with a broader distribution with a peak in expression before postnatal day 7, particularly in cortex and thalamus, and much reduced levels after postnatal day 14 (Burazin et al., 2000).

\section{GALANIN RECEPTOR TYPE 3}

Galanin receptor type 3 (GalR3) was first isolated from rat hypothalamic cDNA libraries (Wang et al., 1997b) and later from human cDNA (Kolakowskim et al., 1998; Smith et al., 1998). The 368 amino acid long hGalR3 shares 36\% amino acids identity with hGalR1 and 58\% with hGalR2 and approximately 90\% with rGalR3 (Kolakowskim et al., 1998).

The distribution pattern of GalR3 is somewhat unclear but it is assumed that this receptor has a more restricted expression pattern in relation to the other two receptors. Transcript levels is most prominent in the hypothalamus (Wang et al., 1997b; Smith 
et al., 1998; Mennicken et al., 2002) although, some studies report a wider distribution of GalR3 throughout central and peripheral tissues (Kolakowskim et al., 1998; Waters and Krause, 2000).

Signaling properties of GalR3 are still ill-defined. Activation of GalR3 expressed in Xenopus oocytes or Xenopus melanophores leads to the activation of $\mathrm{G} \alpha_{\mathrm{i}} / \alpha_{\mathrm{o}}$ type of G-proteins inhibiting AC which results in the opening of GIRK channels (Kolakowskim et al., 1998; Smith et al., 1998).

\section{PEPTIDE LIGANDS FOR THE GALANIN RECEPTORS}

Endogenous galanin has high affinity for all three galanin receptors (Wang et al., 1997b). The N-terminal part of galanin is crucial for receptor interaction and the galanin fragment galanin (1-16) retains the high affinity of its parental peptide. When galanin (1-16) underwent an L-alanine scan and subsequent testing on rat hypothalamus membranes, Gly ${ }^{1}, \operatorname{Trp}^{2}, \mathrm{Asn}^{5}, \mathrm{Tyr}^{9}$, and Gly ${ }^{12}$ were identified as pharmacophores (Land et al., 1991b). A later study, which tested an identical set of peptides on separated GalR1 and GalR2 membranes, identified $\operatorname{Trp}^{2}$, Tyr ${ }^{9}$, and Leu ${ }^{10}$ as pharmacophores on both receptor subtypes (Carpenter et al., 1999).

Several N-terminal truncated galanin fragments have been shown to have a preference for GalR2 (Wang et al., 1997b; Liu et al., 2001), in concurrence with the fact that $\mathrm{Gly}^{1}$ is of great importance for ligand binding to GalR1. Further truncation, with as little as two amino acids, leads to a complete loss of receptor affinity to all receptor subtypes (Wang et al., 1997a).

Liu et al. (2001) published the galanin fragment galanin (2-11) as a GalR2 selective agonist, although they did not test it on GalR3
(Table 3). Later publication has unfortunately shown that it has similar affinity toward GalR3 (Lu et al., 2005a), without testing receptor signaling, even so, it has been used extensively as a nonGalR1 agonist. Lundström and colleagues showed that $\operatorname{Trp}^{2}, \mathrm{Asn}^{5}$, $\mathrm{Gly}^{8}$, $\mathrm{Tyr}^{9}$, and $\mathrm{Leu}^{10}$ were identified as crucial for interactions with GalR2 by performing Ala-scan on the peptide (Lundström et al., 2005a).

The interaction between the galanin receptor subtypes and GALP has received less attention. GALP, isolated from porcine tissues, was original published as a GalR2 preferring ligand, with a 20 times difference in affinity between GalR1 and GalR2 (Ohtaki et al., 1999). Later it was shown, using human GALP, that GALP also interacts with GalR3. In this study GALP was ascribed a GalR3 preferential selectivity (3 times differences; Lang et al., 2005). Recently, Boughton et al. (2010) showed a more than 10 times preferential binding toward GalR3 for the rat GALP (Table 2).

Several chimeric ligands have been synthesized, conjugating galanin (1-13) to other bioactive molecules, yielding M15 (also called galantide; Bartfai et al., 1991), M32 (Wiesenfeld-Hallin et al., 1992b), M35 (Wiesenfeld-Hallin et al., 1992b, Ögren et al., 1992, Kask et al., 1995), C7 (Langel et al., 1992), and M40 (Langel et al., 1992; Bartfai et al., 1993). Although, they all maintain antagonistic properties in vivo at doses between 0.1 and $10 \mathrm{nmol}$ when delivered i.c.v. or intrathecally (i.t.; Parker et al., 1995; Lu et al., 2005b), they all have a partial agonistic nature in vivo at doses higher than $10 \mathrm{nmol}$ when delivered i.c.v. or i.t. (Kask et al., 1995; Lu et al., 2005b).

The first introduced chimeric peptide which acts as an antagonist of the galanin receptor family was M15 (Bartfai et al., 1991).

Table 3 | Published ligands and their affinities for the galanin receptor subtypes.

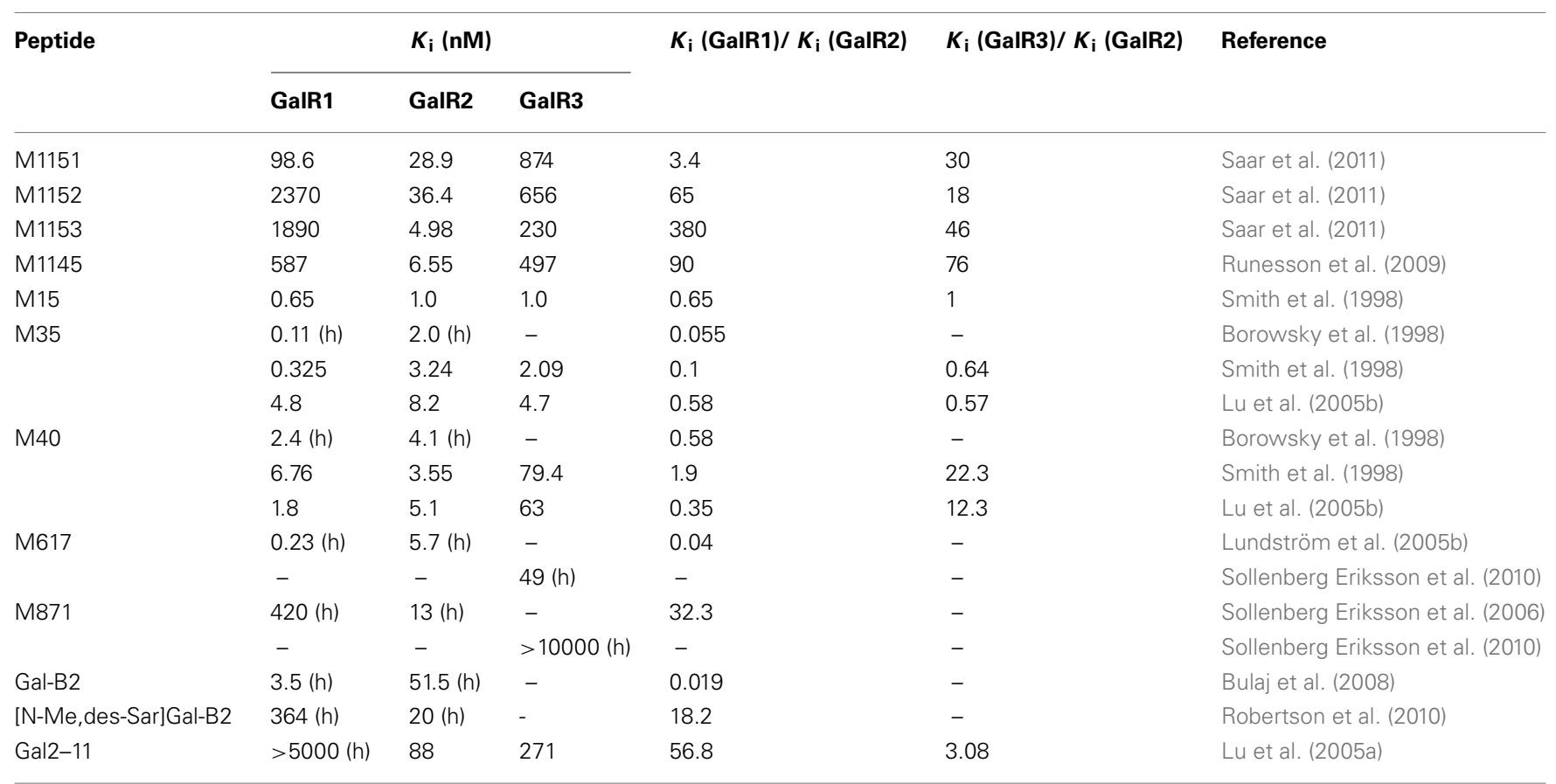

The sequences and structures of the ligands are listed in Table 4.

Displacement was performed on the rat galanin receptor unless indicated otherwise. (h) human; - not determined. 
Table 4 | The sequences for the galanin family peptides along with the discussed analogs.

Name

\section{Sequence}

\section{GALANINFAMILY}

Rat galanin(1-29)

Human galanin(1-30)

Porcine galanin(1-29)

Galanin(1-16)

Rat Galanin(2-29)

Rat Galanin(3-29)

Galanin(2-11)

Porcine GALP

Human GALP

Human GALP(1-32)

Human GALP(3-32)

Rat GALP

Alarin

$\operatorname{GMAP}(1-41)$

GMAP(44-59)

\section{PEPTIDE LIGANDS}

\section{M1151}

M1152

M1153

M1145

M15

M35

M40

M617

M871

Gal-B2

[N-Me,des-Sar]Gal-B2

\section{NON-PEPTIDE LIGANDS}

Galnon<smiles>CCCCC[C@H](NC(=O)[C@H](CC1CCCCC1)NC(=O)OCC1c2ccccc2-c2ccccc21)C(=O)Nc1ccc2c(C)cc(=O)oc2c1</smiles>

Galmic

Galnon
GWTLNSAGYLLGPHAIDNHRSFSDKHGLT-amide

GWTLNSAGYLLGPHAVGNHRSFSDKNGLTS

GWTLNSAGYLLGPHAIDNHRSFHDKYGLA-amide

GWTLNSAGYLLGPHAl-amide (rat/porcine)

GWTLNSAGYLLGPHAV-amide (human)

WTLNSAGYLLGPHAIDNHRSFSDKHGLT-amide

TLNSAGYLLGPHAIDNHRSFSDKHGLT-amide

WTNLSAGYLL-amide

APVHRGRGGWTLNSAGYLLGPVLHPPSRAEGGGKGKTALGILDWKAIDGLPYPOSOLAS

APAHRGRGGWTLNSAGYLLGPVLHLPQMGDQDGKRETALEILDLWKAIDGLPYSHPPOPS

APAHRGRGGWTLNSAGYLLGPVLHLPQMGDOD

AHRGRGGWTLNSAGYLLGPVLHLPOMGDOD

APAHRGRGGWTLNSAGYLLGPVLHPPSRAEGGGKGKTALGILDLWKAIDGLPYPOSOLAS

APAHRSSTFPKWVTKTERGROPLRS (human)

APAHRSSPFPPRPTRAGRETOLLRS (mouse)

ELPLEVEEGRLGSVAVPLPESNIVRTIMEFLSFLHLKEAGA (rat)

SLGIPLATSSEDLEQS (rat)

GWTLNSAGYLLGPK( $\varepsilon-N H-C(O) G l u)$-amide

WTLNSAGYLLGPK( $\varepsilon-\mathrm{NH}-\mathrm{C}(\mathrm{O}) \mathrm{Glu}$ )-amide

RGRGNWTLNSAGYLLGPK( $(\varepsilon-N H-C(O) G l u)$-amide

RGRGNWTLNSAGYLLGPVLPPPALALA-amide

GWTLNSAGYLLGPQQFFGLM-amide

GWTLNSAGYLLGPPPGFSPFR-amide

GWTLNSAGYLLGPPPALALA-amide

GWTLNSAGYLLGPOPGFSPFR-amide

WTLNSAGYLLGPEHPPPALALA-amide

(Sar)WTLNSAGYLLGPKKK(palmitoyl)K-amide

(N-Me)WTLNSAGYLLGPKKK(palmitoyl)K-amide

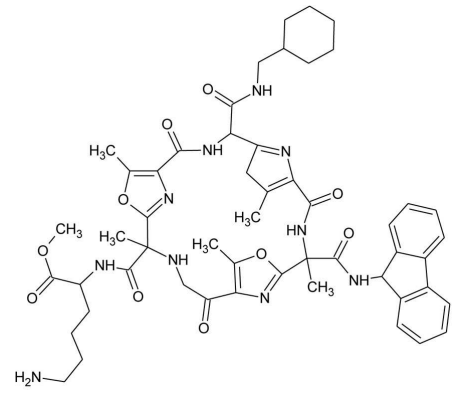

GalR1 agonist

GalR1-3 agonist 
Table 4 | Continued

\section{Name}

Sch 202596

Dithiepine-1, 1,4,4,-tetroxide

SNAP 37889

SNAP 398299
Sequence

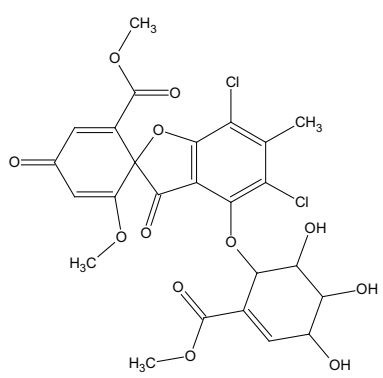

GalR1 antagonist<smiles>O=S1(=O)CCCCCS(=O)(=O)CCCC1</smiles><smiles>O=C1/C(=N\c2cccc(C(F)(F)F)c2)c2ccccc2N1c1ccccc1</smiles>

GalR3 antagonist

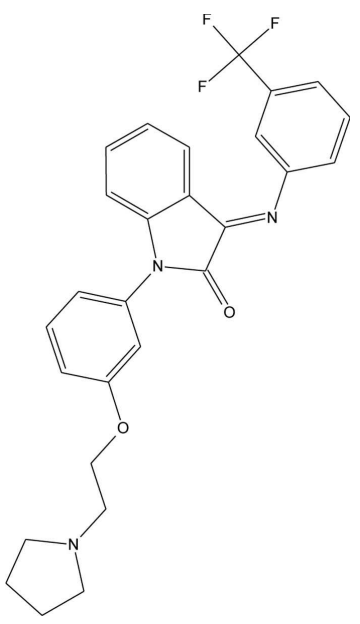

GalR3 antagonist
Here, the galanin (1-13) fragment, was coupled to a C-terminal fragment in substance $\mathrm{P}$ (residue 5-11), reported to have agonistic effect on the substance P receptor. M15 showed an about 10-fold higher affinity than the endogenous galanin to unspecified subtypes of the galanin receptor family in membrane preparations of rat tissues. Later, M35 was synthesized (Ögren et al., 1992) with an improved in vivo stability (Wiesenfeld-Hallin et al., 1992b). M15, M32, M35, and M40 have similar affinity as galanin and have been valuable tools in galanin research but are limited by their relative non-specificity toward the different galanin receptors (Ögren et al., 1992) and by their weak interactions with other receptors than the galanin receptors (Wiesenfeld-Hallin et al., 1992a).

M617 resembles the M35 peptide, with the substitution of proline at position 14 to a glutamine, which results in a 25 fold selectivity for GalR1 over GalR2 in vitro (Table 3). M617 


Game Sequence

has thereafter been shown to produce anti-nociceptive effects (Jimenez-Andrade et al., 2006) and to delay the development of seizure in an animal model (Mazarati et al., 2006). The M871 peptide is N-terminally truncated and has two additional amino acid residues compared to the M40 peptide and function as a partial agonist, selective for GalR2 (Sollenberg Eriksson et al., 2006, 2010). M871 has been used in several in vivo studies (JimenezAndrade et al., 2006; Alier et al., 2007; Kuteeva et al., 2008). Several GalR2 selective agonists have been reported over the years (Pooga et al., 1998; Runesson et al., 2009; Saar et al., 2011). Small changes in the $\mathrm{N}$-terminus of galanin have been associated with lost binding affinity. However, recently analogues with modifications at both $\mathrm{N}$-terminus and C-terminus have been presented, namely M1145 (Runesson et al., 2009) and M1153 (Saar et al., 2011). M1145 was reported as the first specific GalR2 agonist with a 90-fold binding preference for GalR2 over GalR1 and 76-fold preference over GalR3 (Runesson et al., 2009). The importance of the development of M1145 and M871 and other subtype selective agonists and antagonists can almost not be overestimated and is the key to a successful delineation of galaninergic system and to identify its potential as a therapeutic target.

Recently, several galanin analogs, all modified by introducing several cationic amino acid residues and a palmitoyl moiety was shown to exhibit improved bioavailability after systemic administration (Bulaj et al., 2008; White et al., 2009). One of these, the Gal-B2, with a slight selectivity toward GalR1 (Table 3), was shown to have anticonvulsant effect in several tested animal models (White et al., 2009). In a later study, Bulaj and colleagues modified Gal-B2 to obtain a ligand with an 18 times preferential binding toward GalR2, which displayed similar anticonvulsant activity as the parental peptide (Robertson et al., 2010). Future characterization will probably identify other potential application of Gal-B2 and other systemically active galanin analogs.

\section{NON-PEPTIDE LIGANDS}

The non-peptide ligand galnon was identified after screening a combinatorial peptidomimetic library (Table 5). It acts as an agonist in functional studies both in vitro and in vivo (Saar et al., 2002; Bartfai et al., 2004). It has been evaluated in models of anxiety and depression (Rajarao et al., 2007), feeding (Abramov et al., 2004), and pain (Wu et al., 2003). Galmic (Table 5) is a nonpeptide agonist with higher affinity for GalR1 compared to GalR2, which under conditions of intrahippocampal administration was 6-fold more potent than galnon in inhibiting self-sustaining status epilepticus (SE), an in vivo model for epilepsy (Bartfai et al., 2004; Ceide et al., 2004). Nevertheless, both galnon and galmic potentials are limited by the fact that they have multiple sites of interactions, i.e., D2 dopamine receptors, grehlin and melanocortin receptors, which produce unwanted physiological effects (Florén et al., 2005; Lu et al., 2005b).

The metabolite Sch 202596 (Table 5), originated from an Aspergillus sp. culture found in an abandoned uranium mine in Tuolemene County California, was found to have a modest affinity to GalR1 in vitro (Chu et al., 1997). Sch 202596 was characterized as a molecule with a spirocoumaranone skeleton and has only partly been synthesized so far (Katoh et al., 2002). Several 1,4-dithiins and dithiipine-1,1,4,4-tetroxides with binding affinity to GalR1 were identified at the R. W. Johnson Pharmaceutical Institute (Scott et al., 2000). The compound 2,3-dihydro-2(4-methylphenyl)-1,4-dithiepine-1,1,4,4-tetroxide (Table 5) was shown to be a submicromolar antagonist. It has an $\mathrm{IC}_{50}$ of $190 \mathrm{nM}$ for GalR1 and above the highest tested concentration $(30 \mu \mathrm{M})$ for GalR2. However, its reactive nature and its low solubility makes it unattractive from a therapeutic point of view. Nevertheless, it has been used and evaluated in several studies (Mahoney et al., 2003; Kozoriz et al., 2006).

A series of 3-imonio-2-indolones were identified as specific GalR3 antagonists, with $\mathrm{K}_{\mathrm{i}}$-values for GalR3 as low as $17 \mathrm{nM}$ 
Table 5 | Affinities of non-peptidergic galanin receptor ligands for the three galanin receptor subtypes, determined as $K_{i}$ on human receptor subtypes.

\begin{tabular}{lcccc}
\hline Ligand & & $\boldsymbol{K}_{\mathbf{i}}$ (nM) & & Reference \\
\cline { 2 - 4 } & GalR1 & GalR2 & GalR3 \\
\hline Galnon & 11700 & 34100 & - & Saar et al. (2002) \\
Galmic & 34200 & $>100000$ & - & Saar et al. (2002) \\
Sch 202596 & 1700 & - & - & Chu et al. (1997) \\
Dithiepine-1,1,4,4-tetroxide & $190^{\mathrm{a}}$ & $>30000^{\mathrm{a}}$ & - & Scott et al. (2000) \\
SNAP 37889 & $>10000$ & $>10000$ & 17.4 & Swanson et al. (2005) \\
SNAP 398299 & $>1000$ & $>1000$ & 5.3 & Swanson et al. (2005) \\
GalR3ant & $>10000$ & $>10000$ & 15 & Barr et al. (2006)
\end{tabular}

The structures of the ligands are listed in Table 4.

Displacement is performed on the rat galanin receptor unless indicated otherwise.

a presented as $I C_{50}$ values; - not determined.

and above the tested $10 \mu \mathrm{M}$ for the other receptors studied (Konkel et al., 2006a). One of these was referred as SNAP37889 (Swanson et al., 2005) (Table 5). One drawback of the above mentioned indolones is the low aqueous solubility (less than $1 \mu \mathrm{g} / \mathrm{ml}$ ) which motivated further studies, leading to the identification of a compound with an increased water solubility and selectivity, 1,3-dihydro-1-[3-(2-pyrrolidinylethoxy)phenyl]3-[[3-(trifluoromethyl)phenyl]imino]-2H-indol-2-one, referred as SNAP398299 (Swanson et al., 2005; Konkel et al., 2006b) (Table 5). Another of the synthesized indolones (Table 5) was evaluated in vivo by Barr et al. (2006), which together with the other articles and several patent applications (Konkel et al., 2004) indicates that specific GalR3 ligands are in development.

A series of 2,4,6-triaminopyrimidines were recently introduced by The Scripps Research Institute (Sagi et al., 2011). They present both GalR1 and GalR2 selective compounds with $\mathrm{K}_{\mathrm{i}}$-values starting from $330 \mathrm{nM}$. Further development of these compounds is likely ongoing and published in due course. Studies from the same institute led to characterization of the first identified allosteric modulator, named CYM2503, for the galanin receptor family, i.e., GalR2 (Lu et al., 2010). CYM2503 failed to displace galanin in binding studies and showed no detectable signaling by itself, but potentiated the effect of galanin when administered simultaneously (Lu et al., 2010).

\section{GALANIN LIGANDS AS POSSIBLE THERAPEUTICS FOR EPILEPSY}

Among the early reported biological effects of galanin were the decreased excitability of myenteric neurons (Tamura et al., 1988) and cardiac ganglia (Konopka et al., 1989). These findings, together with reports that the hippocampus, which is a key structure for the initiation and maintenance of seizures, have a considerable amount of galaninergic innervation (Lu et al., 2005b) draw attention to galanin as a possible anticonvulsant (Mitsukawa et al., 2008).

Mazarati et al. (1992) reported that galanin had an anticonvulsant effect in a picrotoxin-kindled seizure model. Since then, galanin has been shown to up-regulated in several models of SE (in adult rats), i.e., in kainic acid-induced SE (Wilson et al., 2005) and after perforant path stimulation-induced SE (Mazarati et al.,
1998). Galanin administrated i.c.v. had anticonvulsant activity in rodents exposed to either PTZ or Li-pilocarpine (Chepurnov et al., 1998; Mazarati et al., 1998, 2000). Similar results were obtained when SE was induced by perforant path stimulation (Mazarati et al., 1998, 2004a).

The galanin receptor subtypes present in the hippocampus have been investigated and both GalR1 and GalR2 are present in relatively high levels (Lu et al., 2005b) with GalR1 mRNA in CA-fields and GalR2-mRNA in the dentate gyrus (Burazin et al., 2000). The involvement of GalR3 in hippocampus is still not well characterized.

GalR1-KO mice displayed a more severe seizure phenotype when SE is induced by either perforant path stimulation or Lipilocarpine exposure but not when induced by KA exposure compared to WT (Mazarati et al., 2004b). Li-pilocarpine exposure resulted in cell death in CA1, an effect that was elevated in GalR1-KO mice (Mazarati et al., 2004b). Inbred mice with a lower expression of GalR1 has a larger cell loss than wildtype littermates in several hippocampal regions when exposed to KA (Kong et al., 2008; Schauwecker, 2010) without any alteration in seizure parameters. Some studies has also reported that GalR1-KO mice exhibit spontaneous epilepsy (Jacoby et al., 2002; Fetissov et al., 2003; McColl et al., 2006) although other studies could not replicate this phenotype (Mazarati et al., 2004b).

GalR2-KO mice display no difference in seizure susceptibility in two model of SE compared to WT (Gottsch et al., 2005). In contrast to the knockout mice, application of a putative GalR2 specific ligand shorten the SSSE duration and decreased the seizure density and seizure episodes in the perforant path stimulation model, but not the duration of single seizure episodes (Mazarati et al., 2004a). Similar effects were reported after addition peptide nucleic antisense (PNA) oligonucleotide that mediated transient downregulation of GalR2. PNA-treatment resulted in an increase in the severity of SSSE after perforant path stimulation (Mazarati et al., 2004a). Increased damage to hilar interneurons was also seen after PNA-application (Mazarati et al., 2004a).

Acute administration of two systemically active non-selective subtype galanin receptor agonists, galnon, and galmic, has been shown to prevent self-sustained seizure activity (Saar et al., 
2002; Bartfai et al., 2004) and penthylenetetrazole (PTZ)-induced seizures (Saar et al., 2002). Galnon has shown to interact with several other receptors (Florén et al., 2005), although the anticonvulsant effect seems to be mediated via GalR1, as pretreatment with a GalR1-specific PNA attenuates its anticonvulsant properties (Saar et al., 2002).

In concordance with this, application of non-selective subtype galanin receptor antagonists has been shown to worsen the severity of SE in several models, i.e., kainic acid-induced seizures (Reiss et al., 2009), hippocampal kindling model (Kokaia et al., 2001), self-sustained SE (SSSE), and PTZ-induced convulsions (Chepurnov et al., 1998; Mazarati et al., 1998, 2000; Saar et al., 2002). A recent study showed that M15, a non-selective subtype galanin receptor antagonist significantly induced cell death in several hippocampal areas although no differences in the latency of onset or duration of severe seizures were seen (Schauwecker, 2010).

Galanin-KO mice have a lower threshold for developing SE after perforant path stimulation or KA exposure compared to WT (Mazarati et al., 2000). Furthermore, Gal-KO mice displayed a neuronal injury in the CA3-region that was not present in WT littermates (Mazarati et al., 2000). In concordance with this, Galanin-OE mice have a higher threshold for SE induced by either perforant path stimulation or PTZ and KA exposure compared to WT (Mazarati et al., 2000). Gal-OE mice have been shown to be less affected during hippocampal kindling, a model for human complex partial epilepsy (Kokaia et al., 2001).

Utilizing a recombinant adeno-associated viral (AAV) system that overexpresses galanin resulted in a dramatic reduction in KA-induced seizure episodes and the total time spent in seizures although no reduction of cell damage was seen (Lin et al., 2003). The same vector delayed the initiation of convulsions at generalized seizure stages and shortened the duration of

\section{REFERENCES}

Abramov, U., Florén, A., Echevarria, D. J., Brewer, A., Manuzon, H., Robinson, J. K., et al. (2004). Regulation of feeding by galnon. Neuropeptides 38 , $55-61$.

Ahmad, S., and Dray, A. (2004). Novel $G$ protein-coupled receptors as pain targets. Curr. Opin. Investig. Drugs 5, $67-70$.

Alier, K. A., Chen, Y., Sollenberg Eriksson, U., Langel, Ü., and Smith, P. A. (2007). Selective stimulation of GalR1 and GalR2 in rat substantia gelatinosa reveals a cellular basis for the anti- and pronociceptive actions of galanin. Pain $137,138-146$.

Andell-Jonsson, S., Xu, I. S., Bartfai, T., Xu, X. J., and WiesenfeldHallin, Z. (1997). The effect of naturally occurring fragments of galanin message-associated peptide on spinal cord excitability in rats. Neurosci. Lett. 235, 154-156.

Ash, B. L., Zanatta, S. D., Williams, S. J., and Djouma, E. (2011). The galanin-3 receptor antagonist, SNAP
37889, reduces operant responding for ethanol in alcohol-preferring rats. Regul. Pept. 166, 59-67.

Badie-Mahdavi, H., Lu, X., Behrens, M. M., and Bartfai, T. (2005). Role of galanin receptor 1 and galanin receptor 2 activation in synaptic plasticity associated with $3^{\prime}, 5^{\prime}$-cyclic AMP response elementbinding protein phosphorylation in the dentate gyrus: studies with a galanin receptor 2 agonist and galanin receptor 1 knockout mice. Neuroscience 133, 591-604.

Bailey, K. R., Pavlova, M. N., Hohmann, J. G., and Crawley, J. N. (2007). Galanin receptor subtype 2 (GalR2) null mutant mice displays an anxiogenic-like phenotype specific to the elevated plus-maze. Pharmacol. Biochem. Behav. 86, 8-20.

Barr, A. M., Kinney, J. W., Hill, M. N., Lu, X., Biros, S., Rebek, J. Jr., et al. (2006). A novel, systemically active, selective galanin receptor type-3 ligand exhibits antidepressant-like activity in preclinical tests. Neurosci. Lett. 405, 111-115.

electrographic after discharges in rats undergoing hippocampal kindling (Kanter-Schlifke et al., 2007). A similar AAV system that overexpresses galanin together with the fibronectin secretory signal sequence succeeded to the attenuation of KA-induced seizures and the neuronal death after KA exposure (Haberman et al., 2003).

A recent study showed that a GalR2 allosteric modulator increased the latency to the first electrographic seizure, decrease the total time in seizure and decreased the mortality in the Li-pilocarpine SE-model (Lu et al., 2010).

Furthermore, acute administration of the systemically active subtype galanin receptor agonist, Gal-B2, with a moderate GalR1 preferential binding, prevents seizures in the $6 \mathrm{~Hz}$ mouse model of pharmacoresistant epilepsy (Bulaj et al., 2008). It was later shown to be active also in other seizure and epilepsy models (White et al., 2009). An analog with a moderate GalR2 preferential binding [Nme, des-Sar] Gal-B2, also prevent seizure in the $6 \mathrm{~Hz}$ mouse model (Robertson et al., 2010). The authors conclude that these GalR1and GalR2 preferential analogs (with 15 and 18 times selectivity, respectively) exhibit similar levels of anticonvulsant activity in the $6 \mathrm{~Hz}$ mouse model.

In summary, the wide involvement of galanin family peptides in physiological and pathological conditions has drawn attention to this neuropeptide family. Among the earliest areas of interests was the usage of galanin as a possible anticonvulsant.

Due to the three different galanin receptors specific expression in the CNS, several attempts have been made trying to characterize the contribution of each receptor and delineate their effects. Unfortunately, more selective or specific ligands are still needed.

Recent publications of stable peptide ligands have made new administration routes available as well as attract attention from the pharmaceutical industry.

Barreto, S. G., Bazargan, M., Zotti, M., Hussey, D. J., Sukocheva, O. A., Peiris, H., et al. (2011). Galanin receptor 3 - a potential target for acute pancreatitis therapy. Neurogastroenterol. Motil. 23, e141-e151.

Bartfai, T., Bedecs, K., Land, T., Langel, Ü., Bertorelli, R., Girotti, P., et al. (1991). M-15: high-affinity chimeric peptide that blocks the neuronal actions of galanin in the hippocampus, locus coeruleus, and spinal cord. Proc. Natl. Acad. Sci. U.S.A. 88, 10961-10965.

Bartfai, T., Langel, Ü., Bedecs, K. Andell, S., Land, T., Gregersen, S., et al. (1993). Galanin-receptor ligand M40 peptide distinguishes between putative galanin-receptor subtypes. Proc. Natl. Acad. Sci. U.S.A. 90, 11287-11291.

Bartfai, T., Lu, X., Badie-Mahdavi, H., Barr, A. M., Mazarati, A., Hua, X. Y., et al. (2004). Galmic, a nonpeptide galanin receptor agonist, affects behaviors in seizure, pain, and forced-swim tests. Proc. Natl. Acad. Sci. U.S.A. 101, 10470-10475.
Bauer, J. W., Lang, R., Jakab, M., and Kofler, B. (2010). "Galanin family of peptides in skin function" in Experientia Supplementum, ed. T. Hökfelt (Basel: Springer), 51-59.

Bedecs, K., Langel, Ü., and Bartfai, T. (1995). Metabolism of galanin and galanin (1-16) in isolated cerebrospinal fluid and spinal cord membranes from rat. Neuropeptides 29, 137-143.

Bloomquist, B. T., Beauchamp, M. R., Zhelnin, L., Brown, S. E., GoreWillse, A. R., Gregor, P., et al. (1998). Cloning and expression of the human galanin receptor GalR2. Biochem. Biophys. Res. Commun. 243, 474-479.

Borowsky, B., Walker, M. W., Huang, L. Y., Jones, K. A., Smith, K. E., Bard, J., et al. (1998). Cloning and characterization of the human galanin GALR2 receptor. Peptides 19, 1771-1781.

Boughton, C. K., Patterson, M., Bewick, G. A., Tadross, J. A., Gardiner, J. V., Beale, K. E., et al. (2010). Alarin stimulates food intake and gonadotrophin release in male rats. Br. J. Pharmacol. 161, 601-613. 
Branchek, T. A., Smith, K. E., Gerald, C., and Walker, M. W. (2000). Galanin receptor subtypes. Trends Pharmacol. Sci. 21, 109-117.

Bulaj, G., Green, B. R., Lee, H. K., Robertson, C. R., White, K., Zhang, L., et al. (2008). Design, synthesis, and characterization of highaffinity, systemically-active galanin analogues with potent anticonvulsant activities. J. Med. Chem. 51, 8038-8047.

Burazin, T. C., Larm, J. A., Ryan, M. C., and Gundlach, A. L. (2000). Galanin-R1 and -R2 receptor mRNA expression during the development of rat brain suggests differential subtype involvement in synaptic transmission and plasticity. Eur. J. Neurosci. 12, 2901-2917.

Burgevin, M. C., Loquet, I., Quarteronet, D., and Habert-Ortoli, E. (1995). Cloning, pharmacological characterization, and anatomical distribution of a rat cDNA encoding for a galanin receptor. J. Mol. Neurosci. 6, 33-41.

Carpenter, K. A., Schmidt, R., Yue, S. Y., Hodzic, L., Pou, C., Payza, K., et al. (1999). The glycine residue in cyclic lactam analogues of galanin(1-16)$\mathrm{NH} 2$ is important for stabilizing an $\mathrm{N}$-terminal helix. Biochemistry 38, 15295-15304.

Ceide, S. C., Trembleau, L., Haberhauer, G., Somogyi, L., Lu, X., Bartfai, T., et al. (2004). Synthesis of galmic: a nonpeptide galanin receptor agonist. Proc. Natl. Acad. Sci. U.S.A. 101, 16727-16732.

Chan-Palay, V. (1988a). Galanin hyperinnervates surviving neurons of the human basal nucleus of Meynert in dementias of Alzheimer's and Parkinson's disease: a hypothesis for the role of galanin in accentuating cholinergic dysfunction in dementia. J. Comp. Neurol. 273, 543-557.

Chan-Palay, V. (1988b). Neurons with galanin innervate cholinergic cells in the human basal forebrain and galanin and acetylcholine coexist. Brain Res. Bull. 21, 465-472.

Chepurnov, S. A., Chepurnova, N. E., and Berdiev, R. K. (1998). Galanin controls excitability of the brain. Ann. N. Y. Acad. Sci. 865, 547-550.

Chu, M., Mierzwa, R., Truumees, I., King, A., Sapidou, E., Barrabee, E., et al. (1997). A new fungal metabolite, Sch 202596, with inhibitory activity in the galanin receptor GALR1 assay. Tetrahedron Lett. 38, 6111-6114.

Ciosek, J., and Cisowska, A. (2003). Centrally administrered galanin modifies vasopressin and oxytocin release from the hypothalamoneurohypophysial system of euhydrated and dehydrated rats. J. Physiol. Pharmacol. 54, 625-641.

Corness, J., Shi, T. J., Xu, Z. Q., Brulet, P., and Hökfelt, T. (1996). Influence of leukemia inhibitory factor on galanin/GMAP and neuropeptide $\mathrm{Y}$ expression in mouse primary sensory neurons after axotomy. Exp. Brain Res. 112, 79-88.

Cunningham, M. J., Scarlett, J. M., and Steiner, R. A. (2002). Cloning and distribution of galanin-like peptide mRNA in the hypothalamus and pituitary of the macaque. Endocrinology 143, 755-763.

Ding, X., MacTavish, D., Kar, S., and Jhamandas, J. H. (2006). Galanin attenuates beta-amyloid (Abeta) toxicity in rat cholinergic basal forebrain neurons. Neurobiol. Dis. 21, 413-420.

Eberhard, N., Mayer, C., Santic, R., Navio, R. P., Wagner, A., Bauer, H. C., et al. (2012). Distribution of alarin immunoreactivity in the mouse brain. J. Mol. Neurosci. 46, 18-32.

Elliott-Hunt, C. R., Pope, R. J., Vanderplank, P., and Wynick, D. (2007). Activation of the galanin receptor 2 (GalR2) protects the hippocampus from neuronal damage. $\mathrm{J}$. Neurochem. 100, 780-789.

Fathi, Z., Cunningham, A. M., Iben, L. G., Battaglino, P. B., Ward, S. A., Nichol, K. A., et al. (1997). Cloning, pharmacological characterization and distribution of a novel galanin receptor. Mol. Brain Res. 51, 49-59.

Fetissov, S. O., Jacoby, A. S., Brumovsky, P. R., Shine, J., Iismaa, T. P., and Hökfelt, T. (2003). Altered hippocampal expression of neuropeptides in seizure-prone GALR1 knockout mice. Epilepsia 44, 1022-1033.

Florén, A., Sollenberg, U., Lundström, L., Zorko, M., Stojan, J., Budihna, M., et al. (2005). Multiple interaction sites of galnon trigger its biological effects. Neuropeptides 39, 547-558.

Fraley, G. S., Leathley, E., Lundy, N., Cheng, E., King, I., and Kofler, B. (2012). Effects of alarin on food intake, body weight and luteinizing hormone secretion in male mice. Neuropeptides 46, 99-104.

Fraley, G. S., Scarlett, J. M., Shimada, I., Teklemichael, D. N., Acohido, B. V., Clifton, D. K., et al. (2004). Effects of diabetes and insulin on the expression of galanin-like peptide in the hypothalamus of the rat. Diabetes $53,1237-1242$.

Fujiwara, K., Adachi, S., Usui, K., Maruyama, M., Matsumoto, H., Ohtaki, T., et al. (2002). Immunocytochemical localization of a galanin-like peptide (GALP) in pituicytes of the rat posterior pituitary gland. Neurosci. Lett. 317 , 65-68.

Gabriel, S. M., Kaplan, L. M., Martin, J. B., and Koenig, J. I. (1989). Tissuespecific sex differences in galaninlike immunoreactivity and galanin mRNA during development in the rat. Peptides 10, 369-374.

Gottsch, M. L., Zeng, H., Hohmann, J. G., Weinshenker, D., Clifton, D. K., and Steiner, R. A. (2005). Phenotypic analysis of mice deficient in the type 2 galanin receptor (GALR2). Mol. Cell. Biol. 25, 4804-4811.

Gustafson, E. L., Smith, K. E., Durkin, M. M., Gerald, C., and Branchek, T. A. (1996). Distribution of a rat galanin receptor mRNA in rat brain. Neuroreport 7, 953-957.

Haberman, R. P., Samulski, R. J., and McCown, T. J. (2003). Attenuation of seizures and neuronal death by adeno-associated virus vector galanin expression and secretion. Nat. Med. 9, 1076-1080.

Habert-Ortoli, E., Amiranoff, B. Loquet, I., Laburthe, M., and Mayaux, J. F. (1994). Molecular cloning of a functional human galanin receptor. Proc. Natl. Acad. Sci. U.S.A. 91, 9780-9783.

Hao, J. X., Shi, T. J., Xu, I. S., Kaupilla, T., Xu, X. J., Hökfelt, T., et al. (1999). Intrathecal galanin alleviates allodynia-like behaviour in rats after partial peripheral nerve injury. Eur. J. Neurosci. 11, 427-432.

Hawes, J. J., Brunzell, D. H., Wynick, D., Zachariou, V., and Picciotto, M. R. (2005). GalR1, but not GalR2 or GalR3, levels are regulated by galanin signaling in the locus coeruleus through a cyclic AMP-dependent mechanism. J. Neurochem. 93, 1168-1176.

Hökfelt, T. (2005). Galanin and its receptors: introduction to the Third International Symposium San Diego, CA, USA, 21-22 October 2004. Neuropeptides 39, 125-142.

Hökfelt, T., Aman, K., Arvidsson, U., Bedecs, K., Ceccatelli, S., Hulting, A. L., et al. (1992). Galanin messageassociated peptide (GMAP)- and galanin-like immunoreactivities: overlapping and differential distributions in the rat. Neurosci. Lett. 142 139-142.

Hökfelt, T., Wiesenfeld-Hallin, Z., Villar, M., and Melander, T. (1987). Increase of galanin-like immunoreactivity in rat dorsal root ganglion cells after peripheral axotomy. Neurosci. Lett. 83, 217-220.

Holub, B. S., Rauch, I., Radner, S., Sperl, W., Hell, M., and Kofler, B.
(2011). Effects of galanin messageassociated peptide and neuropeptide $\mathrm{Y}$ against various non-albicans Candida strains. Int. J. Antimicrob. Agents 38, 76-80.

Howard, A. D., Tan, C., Shiao, L. L. Palyha, O. C., McKee, K. K., Weinberg, D. H., et al. (1997). Molecular cloning and characterization of a new receptor for galanin. FEBS Lett. 405, 285-290.

Izdebska, K., and Ciosek, J. (2010). Galanin influences on vasporessin and oxytocin release: in vitro studies. Neuropeptides 44, 341-348.

Jacoby, A. S., Hort, Y. J., Constantinescu, G., Shine, J., and Iismaa, T. P. (2002). Critical role or GALR1 galanin receptor in galanin regulation of neuroendocrine function and seizure activity. Brain Res. Mol. Brain Res. 107, 195-200.

Jacoby, A. S., Webb, G. C., Liu, M. L., Kofler, B., Hort, Y. J., Fathi, Z., et al. (1997). Structural organization of the mouse and human GALR1 galanin receptor genes (Galnr and GALNR) and chromosomal localization of the mouse gene. Genomics 45, 496-508.

Jimenez-Andrade, J. M., Lundström, L., Sollenberg Eriksson, U., Langel, Ü., Castañeda-Hernandez, G., and Carlton, S. M. (2006). Activation of peripheral galanin receptors: differential effects on nociception. Pharmacol. Biochem. Behav. 85, 273-280.

Juréus, A., Cunningham, M. J., Li, D., Johnson, L. L., Krasnow, S. M., Teklemichael, D. N., et al. (2001). Distribution and regulation of galaninlike peptide (GALP) in the hypothalamus of the mouse. Endocrinology $142,5140-5144$.

Juréus, A., Cunningham, M. J., McClain, M. E., Clifton, D. K., and Steiner, R. A. (2000). Galanin-like peptide (GALP) is a target for regulation by leptin in the hypothalamus of the rat. Endocrinology 141, 2703-2706.

Kakuyama, H., Kuwahara, A., Mochizuki, T., Hoshino, M., and Yanaihara, N. (1997). Role of $\mathrm{N}$-terminal active sites of galanin in neurally evoked circular muscle contractions in the guinea-pig ileum. Eur. J. Pharmacol. 329, 85-91.

Kanter-Schlifke, I., Toft Sørensen, A., Ledri, M., Kuteeva, E., Hökfelt, T., and Kokaia, M. (2007). Galanin gene transfer curtails generalized seizures in kindled rats without altering hippocampal synaptic plasticity. Neuroscience 150, 984-992.

Kaplan, L. M., Gabriel, S. M., Koenig, J. I., Sunday, M. E., Spindel, E. R., Martin, J. B., et al. (1988). Galanin is an estrogen-inducible, secretory 
product of the rat anterior pituitary. Proc. Natl. Acad. Sci. U.S.A. 85, 7408-7412.

Kask, K., Berthold, M., Bourne, J., Andell, S., Langel, Ü., and Bartfai, T. (1995). Binding and agonist/antagonist actions of M35, galanin(1-13)-bradykinin(29)amide chimeric peptide, in Rin $m$ 5F insulinoma cells. Regul. Pept. 59, 341-348.

Katoh, T., Ohmori, O., Iwasaki, K., and Inoue, M. (2002). Synthetic studies on Sch 202596, an antagonist of the galanin receptor GalR1: an efficient synthesis of $( \pm)$-geodin, the spirocoumaranone part of Sch 202596. Tetrahedron 58, 1289-1299.

Kauffman, A. S., Buenzle, J., Fraley, G. S., and Rissman, E. F. (2005). Effects of galanin-like peptide (GALP) on locomotion, reproduction, and body weight in female and male mice. Horm. Behav. 48, 141-151.

Kerr, N. C., Holmes, F. E., and Wynick, D. (2000). Galanin-like peptide (GALP) is expressed in rat hypothalamus and pituitary, but not in DRG. Neuroreport 11, 3909-3913.

Kofler, B., Berger, A., Santic, R., Moritz, K., Almer, D., Tuechler, C., et al. (2004). Expression of neuropeptide galanin and galanin receptors in human skin. J. Invest. Dermatol. 122, 1050-1053.

Kofler, B., Evans, H. F., Liu, M. L., Falls, V., Iismaa, T. P., Shine, J., et al. (1995). Characterization of the $5^{\prime}$-flanking region of the human preprogalanin gene. DNA Cell Biol. 14, 321-329.

Kokaia, M., Holmberg, K., Nanobashvili, A., Xu, Z. Q., Kokaia, Z., Lendahl, U., et al. (2001). Suppressed kindling epileptogenesis in mice with ectopic overexpression of galanin. Proc. Natl. Acad. Sci. U.S.A. 98, 14006-14011.

Kolakowskim, L. F. Jr., O’Neill, G. P., Howardm, A. D., Broussard, S. R., Sullivan, K. A., Feighner, S. D., et al. (1998). Molecular characterization and expression of cloned human galanin receptors GALR2 and GALR3. J. Neurochem. 71, 2239-2251.

Kong, S., Lorenzana, A., Deng, Q., McNeill, T. H., and Schauwecker, P. E. (2008). Variation in Galrl expression determines susceptibility to excitotoxin-induced cell death in mice. Genes Brain Behav. 7, 587-598.

Konkel, M., Wetzel, J. M., and Talisman, I. J. (2004). 3-Imino-2-indolones for the treatment of depression and/or anxiety. United States Patent. US7,166,635 B2 (accessed January $23,2007)$.
Konkel, M. J., Lagu, B., Boteju, L. W., Jimenez, H., Noble, S., Walker, M. W., et al. (2006a). 3-arylimino-2indolones are potent and selective galanin GAL3 receptor antagonists. J. Med. Chem. 49, 3757-3758.

Konkel, M. J., Packiarajan, M., Chen, H., Topiwala, U. P., Jimenez, H., Talisman, I. J., et al. (2006b). Amino substituted analogs of 1phenyl-3-phenylimino-2-indolones with potent galanin Gal3 receptor binding affinity and improved solubility. Bioorg. Med. Chem. Lett. 16, 3950-3954.

Konopka, L. M., McKeon, T. W., and Parsons, R. L. (1989). Galanininduced hyperpolarization and decreased membrane excitability of neurones in mudpuppy cardiac ganglia. J. Physiol. 410, 107-122.

Kozoriz, M. G., Kuzmiski, J. B., Hirasawa, M., and Pittman, Q. J. (2006). Galanin modulates neuronal and synaptic properties in the rat supraoptic nucleus in a use and state dependent manner. J. Neurophysiol. 96, 154-164.

Krasnow, S. M., Hohmann, J. G., Gragerov, A., Clifton, D. K., and Steiner, R. A. (2004). Analysis of the contribution of galanin receptors 1 and 2 to the central actions of galanin-like peptide. Neuroendocrinology 79, 268-277.

Kuteeva, E., Wardi, T., Lundström, L., Sollenberg, U., Langel, Ü., Hökfelt, T., et al. (2008). Differential role of galanin receptors in the regulation of depression-like behavior and monoamine/stress-related genes at the cell body level. Neuropsychopharmacology 33, 2573-2585.

Land, T., Langel, Ü., and Bartfai, T. (1991a). Hypothalamic degradation of galanin(1-29) and galanin(1-16): identification and characterization of the peptidolytic products. Brain Res. 558, 245-250.

Land, T., Langel, Ü., Low, M., Berthold, M., Undén, A., and Bartfai, T. (1991b). Linear and cyclic Nterminal galanin fragments and analogs as ligands at the hypothalamic galanin receptor. Int. J. Pept. Prot. Res. 38, 267-272.

Lang, R., Berger, A., Santic, R., Geisberger, R., Hermann, A., Herzog, H., et al. (2005). Pharmacological and functional characterization of galanin-like peptide fragments as potent galanin receptor agonists. Neuropeptides 39, 179-184.

Lang, R., Gundlach, A. L., and Kofler, B. (2007). The galanin peptide family: Receptor pharmacology, pleiotropic biological actions, and implications in health and disease. Pharmacol. Ther. 115, 177-207.

Langel, U., Land, T., and Bartfai, T. (1992). Design of chimeric peptide ligands to galanin receptors and substance P receptors. Int. J. Pept. Protein Res. 39, 516-522.

Larm, J. A., and Gundlach, A. L. (2000). Galanin-like peptide (GALP) mRNA expression is restricted to arcuate nucleus of hypothalamus in adult male rat brain. Neuroendocrinology $72,67-71$.

Lawrence, C. B. (2009). Galanin-like peptide modulates energy balance by affecting inflammatory mediators. Physiol. Behav. 97, 515-519.

Lin, E.-J. D., Richichi, C., Young, D., Baer, K., Vezzani, D., and During, M. J. (2003). Recombinant AAVmediated expression of galanin in rat hippocampus suppresses seizure development. Eur. J. Neurosci. 18, 2087-2092.

Liu, E. J., Richichi, C., Young, D. Baer, K., Vezzani, A., and During, M. J. (2003). Recombinant AAVmediated expression of galanin in rat hippocampus suppresses seizure development. Eur. J. Neurosci. 18, 2087-2092.

Liu, H. X., Brumovsky, P., Schmidt, R., Brown, W., Payza, K., Hodzic, L., et al. (2001). Receptor subtypespecific pronociceptive and analgesic actions of galanin in the spinal cord: selective actions via GalR1 and GalR2 receptors. Proc. Natl. Acad. Sci. U.S.A. 98, 9960-9964.

Lorimer, D. D., and Benya, R. V. (1996). Cloning and quantification of galanin-1 receptor expression by mucosal cells lining the human gastrointestinal tract. Biochem. Biophys. Res. Commun. 222, 379-385.

Lu, X., Lundström, L., and Bartfai, T. (2005a). Galanin (2-11) binds to GalR3 in transfected cell lines: limitations for pharmacological definition of receptor subtypes. Neuropeptides 39, 165-167.

Lu, X., Lundström, L., Langel, Ü., and Bartfai, T. (2005b). Galanin receptor ligands. Neuropeptides 39, 143-146.

Lu, X., Roberts, E., Xia, F., SanchezAlavez, M., Liu, T., Baldwin, R., et al. (2010). GalR2-positive allosteric modulator exhibits anticonvulsant effects in animal models. Proc. Natl. Acad. Sci. U.S.A. 107, 15229-15234.

Lundkvist, J., Land, T., Kahl, U., Bedecs, K., and Bartfai, T. (1995). cDNA sequence, ligand biding, and regulation of galanin/GMAP in mouse brain. Neurosci. Lett. 200, 121-124.

Lundström, L., Lu, X., Langel, Ü., and Bartfai, T. (2005a). Important pharmacophores for binding to galanin receptor 2. Neuropeptides 39 , 169-171.

Lundström, L., Sollenberg, U., Brewer, A., Kouya, P. F., Zheng, K., Xu, X. J., et al. (2005b). A Galanin Receptor Subtype 1 Specific Agonist. Int. J. Pept. Res. Ther. 11, 17-27.

Mahoney, S. A., Hosking, R., Farrant, S., Holmes, F. E., Jacoby, A. S., Shine, J., et al. (2003). The second galanin receptor GalR2 plays a key role in neurite outgrowth from adult sensory neurons. J. Neurosci. 23, 416-421.

Man, P. S., and Lawrence, C. B. (2008a). The effects of galanin-like peptide on energy balance, body temperature and brain activity in the mouse and rat are independent of the GALR2/3 receptor. J. Neuroendocrinol. 20, 128-137.

Man, P. S., and Lawrence, C. B. (2008b). Interleukin-1 mediates the anorexic and febrile actions of galanin-like Peptide. Endocrinology 149, 5791-5580.

Mazarati, A., Lu, X., Kilk, K., Langel, Ü., Wasterlain, C., and Bartfai, T. (2004a). Galanin type 2 receptors regulate neuronal survival, susceptibility to seizures and seizureinduces neurogenesisin the dentate gyrus. Eur. J. Neurosci. 19, 3235-3244.

Mazarati, A., Lu, X., Shinmei, S., BadieMahdavi, H., and Bartfai, T. (2004b). Patterns of seizures, hippocampal injury and neurogenesis in the three models of status epilepticus in galanin receptor type 1 (GalR1) knockout mice. Neuroscience 128 , 431-441.

Mazarati, A., Lundström, L., Sollenberg, U., Shin, D., Langel, Ü., and Sankar, R. (2006). Regulation of kindling epileptogenesis by hippocampal galanin type 1 and type 2 receptors: The effects of subtype-selective agonists and the role of G-proteinmediated signaling. J. Pharm. Exp. Ther. 318, 700-708.

Mazarati, A. M., Liu, H., Soomets, U., Sankar, R., Shin, D., Katsumori, H., et al. (1998). Galanin modulation of seizures and seizure modulation of hippocampal galanin in animal models of status epilepticus. J. Neurosci. 814, 179-185.

Mazarati, A. M., Halászi, E., and Telegdy, G. (1992). Anticonvulsive effects of galanin administered into the central nervous system upon picrotoxinkindeled seizure syndrome in rats. Brain Res. 589, 164-166.

Mazarati, A. M., Hohmann, J. G., Bacon, A., Liu, H., Sankar, R., Steiner, R. A., et al. (2000). Modulation of hippocampal excitability and 
seizures by galanin. J. Neurosci. 20, 6276-6281.

McColl, C. D., Jacoby, A. S., Shine, J., Iismaa, T. P., and Bekkers, J. M. (2006). Galanin receptor-1 knockout mice exhibit spontaneous epilepsy, abnormal EEGs and altered inhibition in the hippocampus. Neuropharmacology 50, 209-218.

Melander, T., Hökfelt, T., Rökaeus, Å., Cuello, A. C., Oertel, W. H., Verhofstad, A., et al. (1986). Coexistence of galanin-like immunoreactivity with catecholamines, 5hydroxytryptamine, GABA and neuropeptides in the rat CNS. J. Neurosci. 6, 3640-3654.

Mennicken, F., Hoffert, C., Pelletier, M., Ahmad, S., and O'Donnell, D. (2002). Restricted distribution of galanin receptor 3 (GalR3) mRNA in the adult rat central nervous system. J. Chem. Neuroanat. 24, 257-268.

Merchenthaler, I., Lopez, F. J., and Negro-Vilar, A. (1990). Colocalization of galanin and luteinizing hormone-releasing hormone in a subset of preoptic hypothalamicneurons: anatomical and functional correlates. Proc. Natl. Acad. Sci. U.S.A. 87, 6326-6330.

Mitchell, V., Bouret, S., Howard, A. D., and Beauvillain, J. C. (1999). Expression of the galanin receptor subtype Gal-R2 mRNA in the rat hypothalamus. J. Chem. Neuroanat. 16, 265-277.

Mitsukawa, K., Lu, X., and Bartfai, T. (2008). Galanin, galanin receptors and drug targets. Cell. Mol. Life. Sci. 65, 1796-1805.

Morris, M. B., Ralston, G. B., Biden, T. J., Browne, C. L., King, G. F., and Iismaa, T. P. (1995). Structural and biochemical studies of human galanin: NMR evidence for nascent helical structures in aqueous solution. Biochemistry 34, 4538-4545.

Narváez, J. A., Diaz-Cabiale, Z., Hedlund, P. B., Aguirre, J. A., Coveñas, R., González-Barón, S., et al. (2000). The galanin receptor antagonist M40 blocks the central cardiovascular actions of the galanin $\mathrm{N}$-terminal fragment (1-15). Eur. J. Pharmacol. 399, 197-203.

O’Donnell, D., Ahmad, S., Wahlestedt, C., and Walker, P. (1999). Expression of the novel galanin receptor subtype GALR2 in the adult rat CNS: distinct distribution from GALR1. J. Comp. Neurol. 409, 469-481.

Ögren, S. O., Hökfelt, T., Kask, K., Langel, Ü., and Bartfai, T. (1992). Evidence for a role of the neuropeptide galanin in spatial learning. Neuroscience $51,1-5$.
Öhman, A., Lycksell, P. O., Juréus, A., Langel, Ü., Bartfai, T., and Gräslund, A. (1998). NMR study of the conformation and localization of porcine galanin in SDS micelles. Comparison with an inactive analog and a galanin receptor antagonist. Biochemistry 37, 9169-9178.

Ohtaki, T., Kumano, S., Ishibashi, Y., Ogi, K., Matsui, H., Harada, M., et al. (1999). Isolation and cDNA cloning of a novel galaninlike peptide (GALP) from porcine hypothalamus. J. Biol. Chem. 274, 37041-37045.

Page, A. J., Slattery, J. A., Brieerley, S. M., Jacoby, A. S., and Blackshaw, L. A. (2007). Invovlement of galanin receptors 1 and 2 in the modulation of mouse vagal afferent mechanosensitivity. J. Physiol. 583, 675-684.

Pang, L., Hashemi, T., Lee, H. J., Maguire, M., Graziano, M. P., Bayne, M., et al. (1998). The mouse GalR2 galanin receptor: genomic organization, cDNA cloning, and functional characterization. J. Neurochem. 71, 2252-2259.

Parker, E. M., Izzarelli, D. G., Nowak, H. P., Mahle, C. D., Iben, L. G., Wang, J., et al. (1995). Cloning and characterization of the rat GALR1 galanin receptor from Rin14B insulinoma cells. Mol. Brain Res. 34, 179-189.

Pirondi, S., Giuliani, A., Del Vecchio, G., Hökfelt, T., and Calzà, L. (2010). The galanin receptor 2/3 agonist Gal2-11 protects the SN56 cells against ( $\beta$ amyloid25-35 toxicity. J. Neurosci. Res. 88, 1064-1073.

Pooga, M., Juréus, A., Razaei, K., Hasanvan, H., Saar, K., Kask, K., et al. (1998). Novel galanin receptor ligands. J. Pept. Res. 51, 65-74.

Potter, E. K., and Smith-White, M. A. (2005). Galanin modulates cholinergic neurotransmission in the heart. Neuropeptides 39, 345-348.

Radács, M., Molnár, A. H., László, F. A., Varga, C., László, F., and Gálfi, M. (2010). Inhibitory Effect of galanin on adrenaline- and noradrenalineinduced increased oxytocin secretion in rat neurohypophyseal cell cultures. J. Mol. Neurosci. 42, 59-66.

Rajarao, S. J., Platt, B., Sukoff, S. J., Lin, Q., Bender, C. N., Nieuwenhuijsen, B. W., et al. (2007). Anxiolytic-like activity of the non-selective galanin receptor agonist, galnon. Neuropeptides $41,307-320$.

Rauch, I., Lundström, L., Hell, M., Sperl, W., and Kofler, B. (2007). Galanin message-associated peptide suppresses growth and the buddedto-hyphal-form transition of
Candida albicans. Antimicrob. Agents Chemother. 51, 4167-4170.

Reiss, J. I., Dishman, R. K., Boyd, H. E., Robinson, J. K., and Holmes, P. V. (2009). Chronic activity wheel running reduces the severity of kainic acid-induced seizures in the rat: possible role of galanin. Brain Res. 1266, 54-63.

Robertson, C. R., Scholl, E. A., Pruess, T. H., Green, B. R., White, H. S., and Bulaj, G. (2010). Engineering galanin analogues that discriminate between GalR1 and GalR2 receptor subtypes and exhibit anticonvulsant activity following systemic delivery. J. Med. Chem. 53, 1871-1875.

Rökaeus, Å., and Carlquist, M. (1988). Nucleotide sequence analysis of cDNAs encoding a bovine galanin precursor protein in the adrenal medulla and chemical isolation of bovine gut galanin. FEBS Lett. 234, 400-406.

Runesson, J., Saar, I., Lundström, L., Järv, J., and Langel, Ü. (2009). A novel GalR2-specific peptide agonist. Neuropeptides 43,187-192.

Saar, I., Runesson, J., McNamara, I., Järv, J., Robinson, J. K., and Langel, Ü. (2011). Novel galanin receptor subtype specific ligands in feeding regulation. Neurochem. Int. 58 714-720

Saar, K., Mazarati, A. M., Mahlapuu, R., Hallnemo, G., Soomets, U., Kilk, K., et al. (2002). Anticonvulsant activity of a nonpeptide galanin receptor agonist. Proc. Natl. Acad. Sci. U.S.A. 99, 7136-7141.

Sagi, V. N., Liu, T., Lu, X., Bartfai, T., and Roberts, E. (2011). Synthesis and biological evaluation of novel pyrimidine derivatives as sub-micromolar affinity ligands of GalR2. Bioorg. Med. Chem. Lett. 21, 7210-7215.

Saito, J., Ozaki, Y., Kawasaki, M. Ohnishi, H., Okimoto, N., Nakamura, T., et al. (2005). Induction of galanin-like peptide gene expression in the arcuate nucleus of the rat after acute but not chronic inflammatory stress. Mol. Brain Res. 133, 233-241.

Saito, J., Ozaki, Y., Ohnishi, H., Nakamura, T., and Ueta, Y. (2003). Induction of galanin-like peptide gene expression in the rat posterior pituitary gland during endotoxin shock and adjuvant arthritis. Mol. Brain Res. 113, 124-132.

Santic, R., Fenninger, K., Graf, K., Schneider, R., Hauser-Kronberger, C., Schilling, F. H., et al. (2006). Gangliocytes in neuroblastic tumors express alarin, a novel peptide derived by differential splicing of the galanin-like peptide gene. J. Mol. Neurosci. 29, 145-152.

Santic, R., Schmidhuber, S. M., Lang, R., Rauch, I., Voglas, E., Eberhard, N., et al. (2007). Alarin is a vasoactive peptide. Proc. Natl. Acad. Sci. U.S.A. 104, 10217-10222.

Schauwecker, P. E. (2010). Galanin receptor 1 deletion exacerbates hippocampal neuronal loss after systemic kainate administration in mice. PLoS ONE 15:e15657. doi:10.1371/journal.pone.0015657

Schneider, E. R., Rada, P., Darby, R., Leibowitz, S. F., and Hoebel, B. G. (2007). Orexigenic peptides and alcohol intake: differential effects of orexin, galanin, and ghrelin. Alcohol. Clin. Exp. Res. 31, 1858-1865.

Scott, M. K., Ross, T. M., Lee, D. H., Wang, H. Y., Shank, R. P., Wild, K. D., et al. (2000). 2,3-Dihydro-dithiin and -dithiepine-1,1,4,4-tetroxides: small molecule non-peptide antagonists of the human galanin hGAL1 receptor. Bioorg. Med. Chem. 8, 1383-1391.

Shen, J., and Gundlach, A. L. (2004). Galanin-like peptide mRNA alterations in arcuate nucleus and neural lobe of streptozotocin-diabetic and obese zucker rats. Further evidence for leptin-dependent and independent regulation. Neuroendocrinology 79, 327-337.

Shen, J., Larm, J. A., and Gundlach, A. L. (2001). Galanin-like peptide mRNA in neural lobe of rat pituitary. Increased expression after osmotic stimulation suggests a role for galanin-like peptide in neuron-glial interactions and/or neurosecretion. Neuroendocrinology 73 , 2-11.

Smith, K. E., Forray, C., Walker, M. W., Jones, K. A., Tamm, J. A., Bard, J., et al. (1997). Expression cloning of a rat hypothalamic galanin receptor coupled to phosphoinositide turnover. J. Biol. Chem 272, 24612-24616.

Smith, K. E., Walker, M. W., Artymyshyn, R., Bard, J., Borowsky, B., Tamm, J. A., et al. (1998). Cloned human and rat galanin GALR3 receptors. Pharmacology and activation of G-protein inwardly rectifying $\mathrm{K}+$ channels. J. Biol. Chem. 273, 23321-23326.

Sollenberg Eriksson, U., Lundström, L. Bartfai, T., and Langel, Ü. (2006). M871 - a novel peptide antagonist selectively recognizingthe galanin receptor type 2. Int. J. Pept. Res. Ther. $12,115-119$.

Sollenberg Eriksson, U., Runesson, J., Sillard, R., and Langel, Ü. (2010). Binding of chimeric peptides M617 
and M871 to galanin receptor type 3 reveals characteristics of galanin receptor-ligand interaction. Int. J. Pept. Res. Ther. 16, 17-22.

Stoyanovitch, A. G., Johnson, M. A., Clifton, D. K., Steiner, R. A., and Fraley, G. S. (2005). Galanin-like peptide rescues reproductive function in the diabetic rat. Diabetes 54, 2471-2476.

Sullivan, K. A., Shiao, L. L., and Cascieri, M. A. (1997). Pharmacological characterization and tissue distribution of the human and rat GALR1 receptors. Biochem. Biophys. Res. Commun. 233, 823-828.

Sun, Y., and Zigmond, R. E. (1996). Involvement of leukemia inhibitory factor in the increases in galanin and vasoactive intestinal peptide mRNA and the decreases in neuropeptide $\mathrm{Y}$ and tyrosine hydroxylase mRNA in sympathetic neurons after axotomy. J. Neurochem. 67, 1751-1760.

Swanson, C. J., Blackburn, T. P., Zhang, X., Zheng, K., Xu, Z. Q., Hökfelt, T., et al. (2005). Anxiolytic- and antidepressant-like profiles of the galanin-3 receptor (Gal3) antagonists SNAP 37889 and SNAP 398299. Proc. Natl. Acad. Sci. U.S.A. 102, 17489-17494.

Takatsu, Y., Matsumoto, H., Ohtaki, T., Kumano, S., Kitada, C., Onda, H., et al. (2001). Distribution of galanin-like peptide in the rat brain. Endocrinology 142, 1626-1634.

Tamura, K., Palmer, J. M., Winkelmann, C. K., and Wood, J. D. (1988). Mechanism of action of galanin on myenteric neurons. J. Neurophysiol. 60, 966-979.

Tatemoto, K., Rökaeus, Å., Jornvall, H., McDonald, T. J., and Mutt, V. (1983). Galanin - a novel biologically active peptide from porcine intestine. FEBS Lett. 164, 124-128.

Taylor, A., Madison, F. N., and Fraley, G. S. (2009). Galanin-like peptide stimulates feeding and sexual behavior via dopaminergic fibers within the medial preoptic area of adult male rats. J. Chem. Neuroanat. 37, 105-111.

van Der Kolk, N., Madison, F. N., Mohr, M., Eberhard, N., Kofler, B., and Fraley, G. S. (2010). Alarin stimulates food intake in male rats and LH secretion in castrated male rats. Neuropeptides 44, 333-340.

Verge, V. M., Richardson, P. M., Wiesenfeld-Hallin, Z., and Hökfelt, T. (1995). Differential influence of nerve growth factor on neuropeptide expression in vivo: a novel role in peptide suppression in adult sensory neurons. J. Neurosci. 15, 2081-2096.

Vrontakis, M. E., Peden, L. M., Duckworth, M. L., and Friesen, H. G. (1987). Isolation and characterization of a complementary DNA (galanin) clone from estrogeninduced pituitary tumor messenger RNA. J. Biol. Chem. 262, 16755-16758.

Vrontakis, M. E., Yamamoto, T., Schroedter, I. C., Nagy, J. I., and Friesen, H. G. (1989). Estrogen induction of galanin synthesis in the rat anterior pituitary gland demonstrated by in situ hybridization and immunohistochemistry. Neurosci. Lett. 100, 59-64.

Wang, S., Hashemi, T., Fried, S., Clemmons, A. L., and Hawes, B. E. (1998). Differential intracellular signaling of the GalR1 and GalR2 galanin receptor subtypes. Biochemistry 37 6711-6717.

Wang, S., Hashemi, T., He, C., Strader, C., and Bayne, M. (1997a). Molecular cloning and pharmacological characterization of a new galanin receptor subtype. Mol. Pharmacol. 52, 337-343.

Wang, S., He, C., Hashemi, T., and Bayne, M. (1997b). Cloning and expressional characterization of a novel galanin receptor. Identification of different pharmacophores within galanin for the three galanin receptor subtypes. J. Biol. Chem. 272, 31949-31952.

Wang, S., He, C., Maguire, M. T., Clemmons, A. L., Burrier, R. E., Guzzi, M. F., et al. (1997c). Genomic organization and functional characterization of the mouse GalR1 galanin receptor. FEBS Lett. 411, 225-230.

Waters, S. M., and Krause, J. E. (2000). Distribution of galanin-1, -2 and -3 receptor messenger RNAs in central and peripheral rat tissues. Neuroscience 95, 265-271.

Wennerberg, A. B., Cooke, R. M., Carlquist, M., Rigler, R., and Campbell, I. D. (1990). A 1H NMR study of the solution conformation of the neuropeptide galanin. Biochem. Biophys. Res. Commun. 166, 1102-1109.

White, H. S., Scholl, E. A., Klein, B. D., Flynn, S. P., Pruess, T. H., Green, B. R., et al. (2009). Developing novel antiepileptic drugs: characterization of NAX 5055, a systemically-active galanin analog, in epilepsy models. Neurotherapeutics 6, 372-380.

Wiesenfeld-Hallin, Z., Bartfai, T., and Hökfelt, T. (1992a). Galanin in sensory neurons in the spinal cord. Front. Neuroendocrinol. 13, 319-343.

Wiesenfeld-Hallin, Z., Xu, X. J., Langel, Ü., Bedecs, K., Hökfelt, T., and Bartfai, T. (1992b). Galanin-mediated control of pain: enhanced role after nerve injury. Proc. Natl. Acad. Sci. U.S.A. 89, 3334-3337.

Wilson, D. N., Chung, H., Elliott, R. C., Bremer, E., George, D., and Koh, S. (2005). Microarray analysis of postical transcriptional regulation of neuropeptides. J. Mol. Neurosci. 25, 285-298.

Wrenn, C. C., Kinney, J. W., Marriott, L. K., Holmes, A., Harris, A. P., Saavedra, M. C., et al. (2004). Learning and memory performance in mice lacking the Gal-R1 subtype of galanin receptor. Eur. J. Neurosci. 19, 1384-1396.

Wu, W. P., Hao, J. X., Lundström, L. Wiesenfeld-Hallin, Z., Langel, Ü. Bartfai, T., et al. (2003). Systemic galnon, a low-molecular weight galanin receptor agonist, reduces heat hyperalgesia in rats with nerve injury. Eur. J. Pharmacol. 482, 133-137.

Xu, X., Yang, X., Zhang, P., Chen, X. Liu, H., and Li, Z. (2012). Effects of exogenous galanin on neuropathic pain state and change of galanin and its receptors in DRG and $\mathrm{SDH}$ after sciatic nerve-pinch injury in rat. PLoS ONE 7:e37621. doi:10.1371/journal.pone.0037621

Xu, X. J., Andell, S., Hao, J. X. Wiesenfeld-Hallin, Z., and Bartfai, T. (1995a). The effects of intrathecal galanin message-associated peptide (GMAP) on the flexor reflex in rats. Regul. Pept. 58, 19-24.

$\mathrm{Xu}, \mathrm{X}$. J., Andell, S., Zhang, X. Wiesenfeld-Hallin, Z., Langel, Ü., Bedecs, K., et al. (1995b). Peripheral axotomy increases the expression of galanin message-associated peptide (GMAP) in dorsal root ganglion cells and alters the effects of intrathecal GMAP on the flexor reflex in the rat. Neuropeptides 28, 299-307.

Xu, Z. Q., Shi, T. J., and Hökfelt, T. (1996). Expression of galanin and a galanin receptor in several sensory systems and bone anlage of rat embryos. Proc. Natl. Acad. Sci. U.S.A. 93, 14901-14905.

Xu, Z. Q., Shi, T. J., and Hökfelt, T. (1998). Galanin/GMAP- and NPY-like immunoreactivities in locus coeruleus and noradrenergic nerve terminals in the hippocampal formation and cortex with notes on the galanin-R1 and -R2 receptors. $J$. Comp. Neurol. 392, 227-251.

Zachariou, V., Georgescu, D., Kansal, L., Merriam, P., and Picciotto, M. R. (2001). Galanin receptor 1 gene expression is regulated by cyclic AMP through a CREBdependent mechanism. J. Neurochem. 76, 191-200.

Zhang, X., Nicholas, A. P., and Hökfelt, T. (1993a). Ultrastructural studies on peptides in the dorsal horn of the spinal cord-I. Co-existence of galanin with other peptides in primary afferents in normal rats. Neuroscience 57, 365-384.

Zhang, X., Verge, V. M., WiesenfeldHallin, Z., Piehl, F., and Hökfelt, T. (1993b). Expression of neuropeptides and neuropeptide mRNAs in spinal cord after axotomy in the rat, with special reference to motoneurons and galanin. Exp. Brain Res. 93, 450-461.

Zhang, X., Nicholas, A. P., and Hökfelt, T. (1995). Ultrastructural studies on peptides in the dorsal horn of the rat spinal cord-II. Co-existence of galanin with other peptides in local neurons. Neuroscience 64, 875-891.

Conflict of Interest Statement: The authors declare that the research was conducted in the absence of any commercial or financial relationships that could be construed as a potential conflict of interest.

Received: 24 August 2012; accepted: 08 November 2012; published online: 07 December 2012.

Citation: Webling KEB, Runesson J, Bartfai T and Langel $\ddot{U}$ (2012) Galanin receptors and ligands. Front. Endocrin. 3:146. doi: 10.3389/fendo.2012.00146

This article was submitted to Frontiers in Neuroendocrine Science, a specialty of Frontiers in Endocrinology.

Copyright (c) 2012 Webling, Runesson, Bartfai and Langel. This is an openaccess article distributed under the terms of the Creative Commons Attribution License, which permits use, distribution and reproduction in other forums, provided the original authors and source are credited and subject to any copyright notices concerning any third-party graphics etc. 